\title{
Technical Note: SWIFT - a fast semi-empirical model for polar stratospheric ozone loss
}

\author{
M. Rex ${ }^{1}$, S. Kremser ${ }^{2}$, P. Huck ${ }^{2}$, G. Bodeker ${ }^{2}$, I. Wohltmann ${ }^{1}$, M. L. Santee ${ }^{3}$, and P. Bernath ${ }^{4}$ \\ ${ }^{1}$ Alfred Wegener Institute for Polar and Marine Research, Potsdam, Germany \\ ${ }^{2}$ Bodeker Scientific, Alexandra, New Zealand \\ ${ }^{3}$ Jet Propulsion Laboratory, California Institute of Technology, Pasadena, California, USA \\ ${ }^{4}$ Old Dominion University, Norfolk, VA, USA \\ Correspondence to: M. Rex (markus.rex@awi.de)
}

Received: 16 October 2013 - Published in Atmos. Chem. Phys. Discuss.: 2 December 2013

Revised: 21 May 2014 - Accepted: 22 May 2014 - Published: 1 July 2014

\begin{abstract}
An extremely fast model to estimate the degree of stratospheric ozone depletion during polar winters is described. It is based on a set of coupled differential equations that simulate the seasonal evolution of vortex-averaged hydrogen chloride $(\mathrm{HCl})$, nitric acid $\left(\mathrm{HNO}_{3}\right)$, chlorine nitrate $\left(\mathrm{ClONO}_{2}\right)$, active forms of chlorine $\left(\mathrm{ClO}_{\mathrm{x}}=\mathrm{Cl}+\mathrm{ClO}+\right.$ $2 \mathrm{ClOOCl})$ and ozone $\left(\mathrm{O}_{3}\right)$ on isentropic levels within the polar vortices. Terms in these equations account for the chemical and physical processes driving the time rate of change of these species. Eight empirical fit coefficients associated with these terms are derived by iteratively fitting the equations to vortex-averaged satellite-based measurements of $\mathrm{HCl}, \mathrm{HNO}_{3}$ and $\mathrm{ClONO}_{2}$ and observationally derived ozone loss rates. The system of differential equations is not stiff and can be solved with a time step of one day, allowing many years to be processed per second on a standard PC. The inputs required are the daily fractions of the vortex area covered by polar stratospheric clouds and the fractions of the vortex area exposed to sunlight. The resultant model, SWIFT (Semiempirical Weighted Iterative Fit Technique), provides a fast yet accurate method to simulate ozone loss rates in polar regions. SWIFT's capabilities are demonstrated by comparing measured and modeled total ozone loss outside of the training period.
\end{abstract}

\section{Introduction}

The importance of stratospheric ozone as a climate-active gas has long been recognized (e.g., Forster and Shine, 1997; Gauss et al., 2006; Forster et al., 2007). Accounting for the interactions between climate change and ozone in climate models is usually accomplished by interactively coupling a stratospheric chemistry module to a global climate model (GCM, defined as a model consisting of a dynamical core and parameterizations for physical processes, but without a chemistry module): dynamical fields from the GCM provide input to the stratospheric chemistry module at a time step compatible with the GCM. The ozone fields generated by the chemistry module are returned to the GCM, which uses them to calculate the radiative forcing. The radiative forcing induces changes in atmospheric temperatures, which in turn influence dynamics, the distribution of trace gases and temperature-dependent chemistry. Such models are generally referred to as chemistry-climate models (CCMs), in contrast to GCMs without a chemistry scheme (Austin, 2002; Eyring et al., 2006, 2007). CCMs are computationally very expensive. Thus, applying them to multiple greenhouse gas (GHG) or ozone-depleting substance (ODS) emissions scenarios is prohibitive. The effects of ozone on climate are therefore usually incorporated into GCMs by prescribing ozone as an external boundary condition. In particular, in the majority of the CMIP5 (Coupled Model Intercomparison Project Phase 5) simulations presented in the report of the Intergovernmental Panel on Climate Change (IPCC), ozone is prescribed (IPCC, 2013, Sect. 9.1.3.2.6). However, this approach results 
in modeled ozone fields that are not internally consistent with the future evolution of the atmosphere in the GCM. Furthermore, prescribed ozone fields are unlikely to be aligned with the internal dynamics of the model; i.e., values typical of the polar vortex may be specified in regions outside of the vortex as a result of vortex excursions within the model, or lower stratospheric air may be prescribed in the upper troposphere if the model has an anomalously high tropopause on that day. In such a model configuration atmospheric dynamics cannot interact with polar ozone chemistry. Incoherence between prescribed ozone and the GCM dynamics is likely to affect ozone radiative forcing and the resultant pattern of surface climate change. Thus, there is a need for fast stratospheric chemistry schemes that can be incorporated into GCMs.

A number of fast stratospheric chemistry schemes have been developed in the past. The Cariolle scheme (Cariolle and Déqué, 1986) expands the ozone continuity equation as a Taylor series up to first order around three variables: the local value of the ozone mixing ratio, the temperature and the overhead ozone column. The eight coefficients for the resultant terms in the expansion are derived from a 2-D photochemical model, independently for each latitude and altitude. The scheme has been used in GCMs to model ozone-climate interactions (Braesicke et al., 2006) and in chemical transport models to simulate ozone trends (Hadjinicolaou et al., 2005). An updated version of the Cariolle scheme, which includes a term for heterogeneous ozone chemistry, is used e.g. in the operational model of the European Centre for MediumRange Weather Forecasts (ECMWF) (Cariolle and Teyssèdre, 2007).

Linoz (McLinden et al., 2000; Hsu and Prather, 2009) is similar to the Cariolle scheme and calculates the net production of ozone as a function of the same three variables as the Cariolle scheme. Small perturbations about a chemical climatology are used to calculate coefficients of a Taylor series expansion of the net production in terms of these three variables. The system is highly constrained, with 7 tables each providing 216 profiles of parameters. Version 1 of Linoz excluded heterogeneous chemistry, and as a result there was no Antarctic ozone hole and no enhanced Arctic ozone loss during cold winters. Version 2 incorporates the polar stratospheric cloud (PSC) parameterization scheme of Cariolle et al. (1990). Both the Cariolle and Linoz schemes rely on a statistical representation of the sensitivity of the ozone tendency to the three controlling variables and are therefore unlikely to be applicable outside of the data set on which they were trained. The FASTOC scheme (Bourqui et al., 2005) uses a large set of pre-computed transfer functions to mimic the response of a stratospheric chemical box model. It is not tuned to present-day conditions and does not include any relaxation to a prescribed climatology in the region of active chemistry.

The SWIFT (Semi-empirical Weighted Iterative Fit Technique) model described in this paper is different in approach from the Cariolle and Linoz schemes. It is a semi-empirical model as defined in the approach of Huck et al. (2013). The first version of SWIFT described in this paper includes heterogeneous polar ozone depletion only, which is by far the strongest anthropogenic perturbation of the state of the ozone layer. The current version of SWIFT is conceived as a "proof of concept", and a version that is better suited for the operational use in a GCM is in development. This version will include a full treatment of extrapolar processes.

Rather than linearizing perturbations about some climatological state, SWIFT describes the seasonal evolution of the key trace gases driving ozone destruction in a set of coupled first-order differential equations. The equations have terms based on the chemical and physical processes known to affect the time evolution of these species. The model is not required to be linear and can cope well with the significant non-linearities occurring in polar ozone chemistry. Since our model is based on an approach that tries to mimic the physical and chemical processes as closely as possible, it is expected to behave more realistically, especially in conditions that move away from the atmospheric mean state. For example, it is easy to change the chlorine loading in the SWIFT model without changing the fit parameters or the model formulation. The model is described in detail in Sect. 2, and a demonstration of its capabilities is presented in Sect. 3 .

\section{Model description}

The purpose of SWIFT is to provide a simple, easy-to-use and numerically efficient process-based description of polar ozone loss. The focus is on numerical efficiency while maintaining the physical and chemical properties of the polar ozone loss process. The model is applicable under a wide range of meteorological and climatic conditions, including future conditions.

To include the chemical mechanisms that are relevant for polar ozone loss, the model describes the evolution of four prognostic variables $\left(\mathrm{ClONO}_{2}, \mathrm{HCl}\right.$, total $\mathrm{HNO}_{3}$ and $\left.\mathrm{O}_{3}\right)$ and two diagnostic variables $\left(\mathrm{ClO}_{\mathrm{x}}=\mathrm{Cl}+\mathrm{ClO}+2 \mathrm{ClOOCl}\right.$ and $\mathrm{HNO}_{3}$ in the gas phase) throughout winter, starting from prescribed initial conditions. All variables represent polar vortex averages of the respective species on a given vertical level; i.e., the model calculates only one value per time step and variable, which is representative for the whole polar vortex at this vertical level. A system of coupled differential equations describes the changes of the prognostic variables due to the relevant chemical mechanisms. The diagnostic variables are derived from the prognostic variables at each time step. The model is driven by the daily values of the fractional vortex area that is cold enough to allow the existence of polar stratospheric clouds (fractional area of PSCs, or FAP) and by the $24 \mathrm{~h}$ average of the fraction of the vortex area that is exposed to sunlight (fractional area of sunlight, or FAS). Time series of FAP and FAS throughout the winter are derived 
from ECMWF ERA Interim meteorological reanalyses (Dee et al., 2011).

SWIFT models the chemical processes that influence lower stratospheric polar ozone. SWIFT calculates chemically induced ozone change rates. In the training described in Sect. 2.3 these rates are fitted to observations of chemical ozone loss rates from the Match program (Rex et al., 1998). Here we only show chemically induced ozone loss rates as calculated by SWIFT, not the ozone field itself. When coupling SWIFT to a GCM, the transport of ozone should be carried out by the advection scheme of the GCM and the chemically induced changes as calculated by SWIFT should be added once a day.

For the other prognostic variables (vortex averages of $\mathrm{ClONO}_{2}, \mathrm{HCl}$ and total $\mathrm{HNO}_{3}$ ) the chemically induced rates of change are much larger than the slow changes due to slow cross-isentropic transport or mixing across the edge of the polar vortex. Hence their seasonal evolution is dominated by chemical processes. For these species the training (Sect. 2.3) is done by fitting the seasonal evolution of their mixing ratios to satellite observations. That means that the small transport-induced changes in these species are implicitly included in the fit parameters. The good performance of the model (see Sect. 3) justifies this approach. Hence, when coupling SWIFT to a GCM, these species do not need to be transported by the GCM.

In this initial version of SWIFT the model runs are performed on one fixed potential temperature surface close to the altitude where maximum ozone loss occurs.

In summary, in its current version SWIFT should be used to calculate ozone loss rates rather than the absolute abundance of ozone. The ozone loss rates from SWIFT can directly be used in a GCM environment that includes the transport of ozone and uses the chemically induced changes from SWIFT to approximate the ozone field.

The implementation of SWIFT into a GCM will basically proceed as follows: the rates of change of ozone in the polar vortex will be calculated for the small number of vertical levels of the GCM which are in the vertical range where heterogeneous ozone depletion is the dominant process. At every level that the SWIFT model is running on, the vortex edge and the appropriate values of the vortex averages of ozone, FAP and FAS will be calculated at the beginning of a $24 \mathrm{~h}$ time step. The only species that is transported is ozone. The other species are represented by a single vortexaverage value per level, which is calculated internally and not communicated to the GCM. These values are initialized at the beginning of the model run and are only modified by the rates of chemical change produced by SWIFT. SWIFT will be run with FAP, FAS and the mixing ratios as input at every level and will return a chemical rate of change for ozone and the other species at every level. The rate of change of ozone will be added to the mixing ratios of ozone of all grid points inside the polar vortex edge. Ozone needs to be transported either with the transport scheme of the GCM or with a future transport module of SWIFT. Outside of the polar vortex, values for the mixing ratios of ozone can be prescribed from a climatology, can be calculated with one of the existing linearized schemes or can be calculated with a future module of SWIFT for extrapolar chemistry (in preparation).

\subsection{Model equations}

Polar ozone chemistry is well understood (e.g., review articles by Solomon, 1999, or von Hobe et al., 2013). Rather than encapsulating this chemistry in full detail, the SWIFT model is conceptual; i.e., instead of representing each individual chemical reaction by individual terms in the equations (as is done in full chemical transport models), the bulk effect of chemical mechanisms is considered.

More than $90 \%$ of the overall chemical loss of ozone during polar winter is due to the combined effect of the $\mathrm{ClO}+$ $\mathrm{ClO}, \mathrm{ClO}+\mathrm{BrO}$ and $\mathrm{ClO}+\mathrm{O}$ catalytic ozone destruction cycles (Frieler et al., 2006). Figure 1a shows that the $24 \mathrm{~h}$ average ozone loss rate by these cycles at $50 \mathrm{hPa}$ is a fairly linear function of the concentration of $\mathrm{ClO}_{\mathrm{x}}(\mathrm{Cl}+\mathrm{ClO}+$ $2 \mathrm{ClOOCl}$ ). The reason is that non-linearities in the dominating $\mathrm{ClO}+\mathrm{ClO}$ and $\mathrm{ClO}+\mathrm{BrO}$ cycles mostly cancel (Fig. $1 \mathrm{~b}$ and $\mathrm{c}$ ).

Since ozone loss can only occur in sunlight, it is also a function of the time that the air mass is exposed to sunlight. Hence, the vortex-average ozone loss can be written as

$\frac{\mathrm{dO}_{3}}{\mathrm{~d} t}=-D$

with

$D=d \cdot\left[\mathrm{ClO}_{\mathrm{x}}\right] \cdot \mathrm{FAS}$,

where [...] denotes the mixing ratio of a species and $d$ is an empirically determined fit parameter (as the parameters $a-$ $h$ and $z$ in the following equations). The detailed approach to determine the values of the parameters is described in Sect. 2.3. In principle $d$ can also be derived from Fig. 1, which would link $d$ to the kinetic parameters in the model that has been used to produce Fig. 1.

Equation (2) shows that estimating the vortex-average ozone loss rate requires good estimates of the evolution of $\mathrm{ClO}_{\mathrm{x}}$ through the winter. To estimate $\mathrm{ClO}_{\mathrm{x}}$, the model needs to represent the key mechanisms that convert the reservoir species $\mathrm{ClONO}_{2}$ and $\mathrm{HCl}$ into $\mathrm{ClO}_{\mathrm{x}}$ and vice versa. Once the concentrations of $\mathrm{ClONO}_{2}$ and $\mathrm{HCl}$ have been determined, the concentration of $\mathrm{ClO}_{\mathrm{x}}$ is calculated from

$\left[\mathrm{ClO}_{\mathrm{x}}\right]=\left[\mathrm{Cl}_{\mathrm{y}}\right]-[\mathrm{HCl}]-\left[\mathrm{ClONO}_{2}\right]$

where $\left[\mathrm{Cl}_{\mathrm{y}}\right]$ is the overall amount of inorganic chlorine, which can be assumed to be constant in an individual air mass during any given polar winter. 


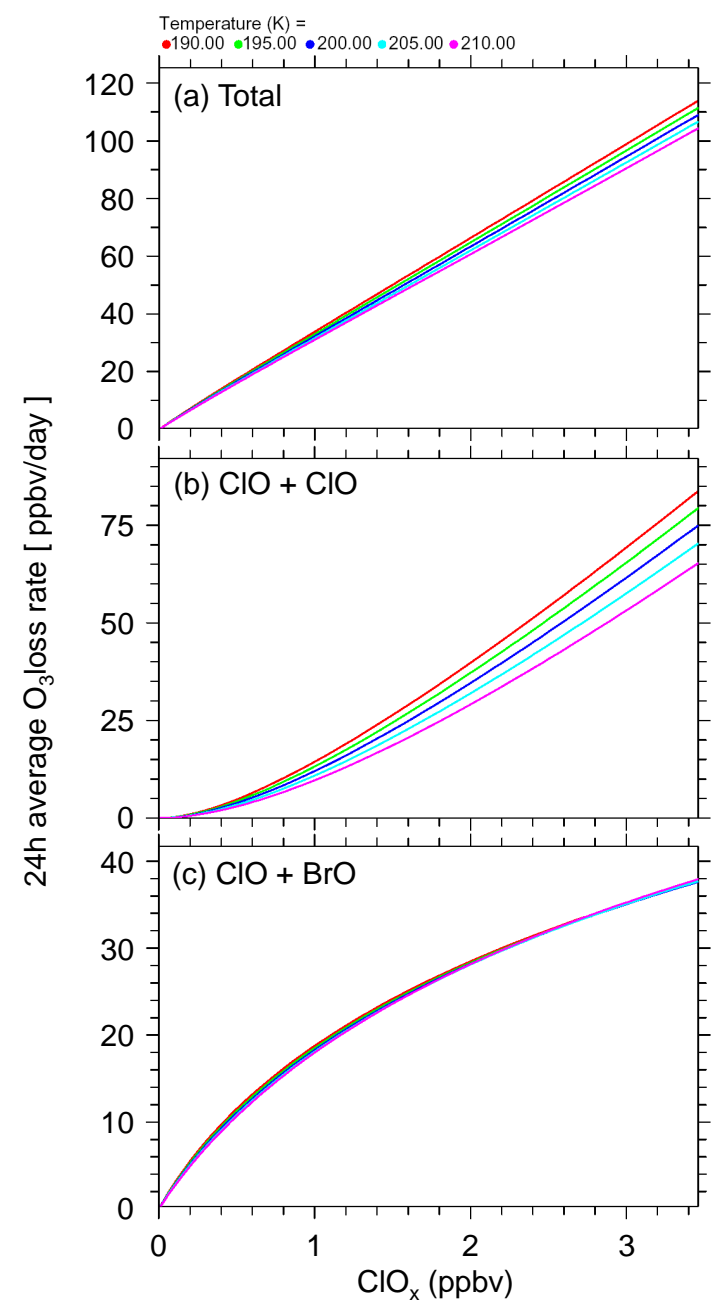

Figure 1. $24 \mathrm{~h}$ ozone loss as a function of $\mathrm{ClO}_{\mathrm{x}}$ mixing ratios at $50 \mathrm{hPa}$. (a) Total, (b) by the $\mathrm{ClO}+\mathrm{ClO}$ catalytic cycle and (c) by the $\mathrm{ClO}+\mathrm{BrO}$ catalytic cycle.

The evolution of vortex-averaged $\mathrm{ClONO}_{2}$ and $\mathrm{HCl}$ is estimated by

$\frac{\mathrm{d}\left[\mathrm{ClONO}_{2}\right]}{\mathrm{d} t}=B-A-G-H$

and

$\frac{\mathrm{d}[\mathrm{HCl}]}{\mathrm{d} t}=C+F-A$,

where $A, B, C, F, G$ and $H$ represent the effects of chlorine activation and deactivation by the chemical mechanisms described in Sects. 2.1.1 and 2.1.2.

The model equations are summarized in Table 1 and the terms used in the equations are given in Table 2. These terms are described in detail below.
Table 1. List of equations used in SWIFT.

\begin{tabular}{l}
\hline Prognostic equations \\
\hline $\mathrm{d}\left[\mathrm{O}_{3}\right] / \mathrm{d} t=-D$ \\
$\mathrm{~d}\left[\mathrm{ClONO}_{2}\right] / \mathrm{d} t=B-A-G-H$ \\
$\mathrm{~d}[\mathrm{HCl}] / \mathrm{d} t=C+F-A$ \\
$\mathrm{~d}\left[\mathrm{HNO}_{3}\right] / \mathrm{d} t=-E$ \\
\hline Diagnostic equations \\
\hline$\left[\mathrm{ClO}_{\mathrm{x}}\right]=\left[\mathrm{Cl}_{\mathrm{y}}\right]-[\mathrm{HCl}]-\left[\mathrm{ClONO}_{2}\right]$ \\
{$\left[\mathrm{HNO}_{3}\right]_{\mathrm{g}}=\left[\mathrm{HNO}_{3}\right] \cdot(1-\mathrm{FAP})+z \cdot\left[\mathrm{HNO}_{3}\right] \cdot \mathrm{FAP}$} \\
\hline
\end{tabular}

\subsubsection{Chlorine activation mechanisms}

Term $A$ describes the loss of $\mathrm{ClONO}_{2}$ and $\mathrm{HCl}$ and the production of $\mathrm{ClO}_{\mathrm{x}}$ due to the heterogeneous reaction

$\mathrm{HCl}+\mathrm{ClONO}_{2} \rightarrow \mathrm{Cl}_{2}+\mathrm{HNO}_{3}$

followed by the photolysis of $\mathrm{Cl}_{2}$

$\mathrm{Cl}_{2}+h v \rightarrow 2 \mathrm{Cl}$.

$\mathrm{Cl}_{2}$ photolyzes readily at wavelengths longer than those required for the ozone loss process. Hence, at sunrise most $\mathrm{Cl}_{2}$ that may have formed during night will photolyze before the sun is high enough for efficient ozone loss to occur. During daytime $\mathrm{Cl}_{2}$ cannot build up in significant quantities. Therefore, the photolysis step can be ignored in a conceptual model of the ozone loss process. In terms of ozone loss the system of Reactions (R1) and (R2) is equivalent to a system that directly produces $\mathrm{ClO}_{\mathrm{x}}$ in the initial heterogeneous Reaction (R1). Unless $\mathrm{HCl}$ is very low, the rate of Reaction (R1) depends only on the surface area density of the PSC particles and the concentration of $\mathrm{ClONO}_{2}$ :

$A=a \cdot\left[\mathrm{ClONO}_{2}\right] \cdot\left[\mathrm{HNO}_{3}\right] \cdot$ FAP.

The factor $\left[\mathrm{HNO}_{3}\right] \cdot$ FAP represents the availability of reactive surfaces in a vortex-average bulk sense.

Only when $\mathrm{HCl}$ concentrations become very low is the reaction also limited by the uptake rate of $\mathrm{HCl}$ on the PSC particles. The rate of Reaction (R1) then also depends on $\mathrm{HCl}$ concentrations. For $\mathrm{HCl}$ concentrations below $1 \%$ of $\mathrm{Cl}_{\mathrm{y}}, A$ is defined as

$A=a \cdot[\mathrm{HCl}] \cdot\left[\mathrm{ClONO}_{2}\right] \cdot\left[\mathrm{HNO}_{3}\right] \cdot \mathrm{FAP}$.

Term $G$ represents the effect of

$\mathrm{ClONO}_{2}+h v \rightarrow \mathrm{Cl}+\mathrm{NO}_{3}$. 
Table 2. List of the terms used in the differential equations.

\begin{tabular}{lll}
\hline Term & Expression & Remark \\
\hline$A$ & $a \cdot\left[\mathrm{ClONO}{ }_{2}\right] \cdot\left[\mathrm{HNO}_{3}\right] \cdot \mathrm{FAP}$ & for $[\mathrm{HCl}]>1 \%$ of $\mathrm{Cl}_{\mathrm{y}}$ \\
& $a \cdot[\mathrm{HCl}] \cdot\left[\mathrm{ClONO}_{2}\right] \cdot\left[\mathrm{HNO}_{3}\right] \cdot \mathrm{FAP}$ & for $[\mathrm{HCl}]<1 \%$ of $\mathrm{Cl}_{\mathrm{y}}$ \\
\hline$B$ & $b \cdot\left[\mathrm{HNO}_{3}\right]_{\mathrm{g}} \cdot \mathrm{FAS}$ & for $\left[\mathrm{ClO}_{\mathrm{x}}\right]>5 \%$ of $\mathrm{Cl}_{\mathrm{y}}$ \\
& $b \cdot\left[\mathrm{ClO}_{\mathrm{x}}\right] \cdot\left[\mathrm{HNO}_{3}\right]_{\mathrm{g}} \cdot \mathrm{FAS}$ & for $\left[\mathrm{ClO}_{\mathrm{x}}\right]<5 \%$ of $\mathrm{Cl}_{\mathrm{y}}$ \\
\hline$C$ & $c \cdot\left[\mathrm{ClO}_{\mathrm{x}}\right] \cdot \mathrm{FAS} /\left[\mathrm{O}_{3}\right]$ & \\
\hline$D$ & $d \cdot\left[\mathrm{ClO}_{\mathrm{x}}\right] \cdot \mathrm{FAS}$ & \\
\hline$E$ & $e \cdot\left[\mathrm{HNO}_{3}\right] \cdot \max ((\mathrm{FAP}-y), 0)$ & Arctic \\
\hline$F$ & $f \cdot\left[\mathrm{ClO}_{\mathrm{x}}\right] \cdot \mathrm{FAS}^{2}$ & Antarctic \\
\hline & $0.25 f \cdot\left[\mathrm{ClO}_{\mathrm{x}}\right] \cdot \mathrm{FAS}$ & \\
\hline$G$ & $g \cdot\left[\mathrm{ClONO}_{2}\right] \cdot \mathrm{FAS}$ & \\
\hline$H$ & $h \cdot\left[\mathrm{ClONO}_{2}\right] \cdot \max ((\mathrm{FAP}-y), 0)$ & \\
\hline
\end{tabular}

The efficiency of this process depends on the concentration of $\mathrm{ClONO}_{2}$ and the availability of sunlight:

$G=g \cdot\left[\mathrm{ClONO}_{2}\right] \cdot$ FAS.

During winter this is a minor loss channel for $\mathrm{ClONO}_{2}$, but in spring it controls the repartitioning between $\mathrm{ClONO}_{2}$ and $\mathrm{HCl}$ in the Arctic. With the exception of the last few weeks in Arctic winters, the model would do well without this term, and it is not very important for the calculated ozone loss.

Term $H$ accounts for the effect of the heterogeneous reaction

$\mathrm{ClONO}_{2}+\mathrm{H}_{2} \mathrm{O} \rightarrow \mathrm{HOCl}+\mathrm{HNO}_{3}$

followed by photolysis of $\mathrm{HOCl}$

$\mathrm{HOCl}+h v \rightarrow \mathrm{Cl}+\mathrm{OH}$.

Reaction (R5) is rapid during daytime. For the purpose of the conceptual model it can be included in Reaction (R4) based on the same arguments that have been discussed for the $\mathrm{Cl}_{2}$ photolysis in term A. Reaction (R4) is efficient only at temperatures well below the PSC formation temperature threshold (Wohltmann et al., 2013). If FAP is large, temperatures in the core part of the cold region will typically be well below the PSC formation temperature threshold, so that term $H$ starts to become relevant. Hence this mechanism is assumed to start being efficient only if FAP exceeds a certain threshold, which is represented by the parameter $y$ :

$H=h \cdot\left[\mathrm{ClONO}_{2}\right] \cdot \max ((\mathrm{FAP}-y), 0)$.

Equation (9) uses only the fraction of FAP that exceeds the threshold of $y$, assuming that only in the central region of large PSC areas will temperatures be sufficiently low to make Reaction (R4) efficient.

\subsubsection{Chlorine deactivation mechanisms}

Term $B$ describes the chlorine deactivation by formation of $\mathrm{ClONO}_{2}$, which results from the photolysis of $\mathrm{HNO}_{3}$ followed by the fast reaction of $\mathrm{NO}_{2}$ with $\mathrm{ClO}$ :

$$
\begin{aligned}
& \mathrm{HNO}_{3}+h v \rightarrow \mathrm{NO}_{2}+\mathrm{OH}, \\
& \mathrm{NO}_{2}+\mathrm{ClO}+\mathrm{M} \rightarrow \mathrm{ClONO}_{2}+\mathrm{M} .
\end{aligned}
$$

Unless $\mathrm{ClO}$ concentrations are very low, Reaction (R7) is fast and can be ignored in the conceptual model

$B=b \cdot\left[\mathrm{HNO}_{3}\right]_{\mathrm{g}} \cdot \mathrm{FAS}$

i.e., $\mathrm{ClONO}_{2}$ is assumed to directly form from Reaction (R6). $\left[\mathrm{HNO}_{3}\right]_{\mathrm{g}}$ denotes the mixing ratio of $\mathrm{HNO}_{3}$ in the gas phase.

If $\mathrm{ClO}_{\mathrm{x}}$, and hence $\mathrm{ClO}$, are very low, Reaction (R7) also limits the production of $\mathrm{ClONO}_{2}$. For $\mathrm{ClO}_{\mathrm{x}}$ less than $5 \%$ of $\mathrm{Cl}_{\mathrm{y}}$

$B=b \cdot\left[\mathrm{ClO}_{\mathrm{x}}\right] \cdot\left[\mathrm{HNO}_{3}\right]_{\mathrm{g}} \cdot \mathrm{FAS}$

is used.

Term $C$ represents the effect of

$\mathrm{Cl}+\mathrm{CH}_{4} \rightarrow \mathrm{HCl}+\mathrm{CH}_{3}$.

This reaction is responsible for deactivation under ozone hole conditions. Once ozone concentrations become very low, the reaction

$\mathrm{Cl}+\mathrm{O}_{3} \rightarrow \mathrm{ClO}+\mathrm{O}_{2}$.

becomes less efficient and the ratio of $\mathrm{Cl}$ over $\mathrm{ClO}$ increases with $1 /\left[\mathrm{O}_{3}\right]$. Since $\mathrm{ClO}_{\mathrm{x}}$ is mainly in the form of $\mathrm{ClOOCl}$ during nighttime, Reaction (R8) can only occur during daytime. Hence its efficiency depends on $\left[\mathrm{ClO}_{\mathrm{x}}\right]$, FAS and $1 /\left[\mathrm{O}_{3}\right]$ :

$C=c \cdot\left[\mathrm{ClO}_{\mathrm{x}}\right] \cdot \mathrm{FAS} /\left[\mathrm{O}_{3}\right]$. 
Term $F$ represents the net effect of the $\approx 8 \%$ channel of the reaction of $\mathrm{ClO}$ with $\mathrm{OH}$, which results in $\mathrm{HCl}$ formation:

$$
\mathrm{ClO}+\mathrm{OH} \rightarrow \mathrm{HCl}+\mathrm{O}_{2} .
$$

This reaction helps $\mathrm{HCl}$ reformation in both hemispheres, but only in late winter since both $[\mathrm{ClO}] /\left[\mathrm{ClO}_{\mathrm{x}}\right]$ and $\mathrm{OH}$ scale with the availability of sunlight. The effect of Reaction (R10) is described by

$$
F=f \cdot\left[\mathrm{ClO}_{\mathrm{x}}\right] \cdot \mathrm{FAS}^{2} \text {. }
$$

Since significant dehydration occurs in the Antarctic, the late winter abundance of total water is reduced to about $25 \%$ of the levels commonly found in the Arctic, also reducing the concentrations of $\mathrm{OH}$ by the same factor. Therefore an additional scaling factor of 0.25 is used in the term $F$ for the Antarctic:

$F=0.25 f \cdot\left[\mathrm{ClO}_{\mathrm{x}}\right] \cdot \mathrm{FAS}^{2}$.

\subsubsection{Sequestration and irreversible removal of $\mathrm{HNO}_{3}$}

The processes described above regulate the balance between $\mathrm{ClO}_{\mathrm{x}}$ and the reservoir gases $\mathrm{HCl}+\mathrm{ClONO}_{2}$. Other than FAP and FAS, the only remaining inputs required to solve the model equations are total and gas-phase $\mathrm{HNO}_{3}$ (cf. Terms $A$ and $B$ in Sects. 2.1.1 and 2.1.2).

Because of strong denoxification during polar winter (heterogeneous conversion of $\mathrm{NO}_{\mathrm{x}}$ into $\mathrm{HNO}_{3}$ on cold background aerosol, where $\mathrm{NO}_{\mathrm{x}}$ denotes the sum of all short-lived nitrogen oxides), $\mathrm{N}_{2} \mathrm{O}, \mathrm{HNO}_{3}$ and $\mathrm{ClONO}_{2}$ are the only nitrogen oxide species that exist at significant abundances at that time. Under polar winter conditions $\mathrm{N}_{2} \mathrm{O}$ is inert, and the abundance of $\mathrm{ClONO}_{2}$ is about an order of magnitude smaller than that of $\mathrm{HNO}_{3}$. Hence, the total abundance of $\mathrm{HNO}_{3}$ is not altered much by chemistry during polar winter.

The only process that significantly changes total $\mathrm{HNO}_{3}$ in the model is denitrification, i.e., the irreversible removal of $\mathrm{HNO}_{3}$ due to sedimentation of $\mathrm{HNO}_{3}$-containing particles. Denitrification only occurs either if individual PSC particles persist sufficiently long (many days) to grow to sizes of a few micrometers or if temperatures fall so low that water ice can accumulate on the PSC particles, which lets them grow rapidly. Both processes require large values of FAP: the slow growth of particles can only occur if air mass trajectories exist that stay within the potential PSC region for many days, requiring large PSC areas. Furthermore, when ice temperatures are reached, conditions are very cold and PSC areas are typically very large. Hence, in the model, the denitrification process is only triggered if the threshold value $y$ for FAP is exceeded:

$$
\frac{\mathrm{d}\left[\mathrm{HNO}_{3}\right]}{\mathrm{d} t}=-E
$$

with

$$
E=e \cdot\left[\mathrm{HNO}_{3}\right] \cdot \max ((\mathrm{FAP}-y), 0) .
$$

The fraction of $\mathrm{HNO}_{3}$ in the gas phase is calculated from the total $\mathrm{HNO}_{3}$ abundance at each time step by

$$
\left[\mathrm{HNO}_{3}\right]_{\mathrm{g}}=\left[\mathrm{HNO}_{3}\right] \cdot(1-\mathrm{FAP})+z \cdot\left[\mathrm{HNO}_{3}\right] \cdot \mathrm{FAP} .
$$

The first term represents the gas-phase $\mathrm{HNO}_{3}$ outside of the area where temperatures are below the PSC formation threshold (here gas phase equals total), and the second term includes the average fraction $z$ of $\mathrm{HNO}_{3}$ still in the gas phase in areas where temperatures are below the PSC threshold. The latter includes the fact that PSCs will only form in parts of the region where they are thermodynamically stable, due to the nucleation barrier (Pitts et al., 2007).

\subsection{Initialization}

The prognostic variables are initialized at the beginning of the winter (1 December in the Arctic and 20 May in the Antarctic). Since the model is conceptual at this stage, the abundances of the chemical species are normalized, and the initial concentrations for the three different families are set to unity:

$$
\begin{aligned}
& {\left[\mathrm{O}_{3}\right](t=0)=1,} \\
& {\left[\mathrm{HNO}_{3}\right](t=0)=1,} \\
& {\left[\mathrm{Cl}_{\mathrm{y}}\right](t=0)=1 .}
\end{aligned}
$$

The partitioning of $\mathrm{Cl}_{\mathrm{y}}$ between $\mathrm{HCl}$ and $\mathrm{ClONO}_{2}$ at $460 \mathrm{~K}$ is taken from Fig. 1 of Harris et al. (2010), which is based on an analysis by Santee et al. (2008) of data from the Microwave Limb Sounder (MLS; Livesey et al., 2011) on the Aura satellite and data from the Fourier transform spectrometer, which is part of the Atmospheric Chemistry Experiment (ACE-FTS; Bernath et al., 2005):

$[\mathrm{HCl}](t=0)=0.65\left[\mathrm{Cl}_{\mathrm{y}}\right]$,

$\left[\mathrm{ClONO}_{2}\right](t=0)=0.35\left[\mathrm{Cl}_{\mathrm{y}}\right]$.

For long-term studies, the secular variation of $\left[\mathrm{Cl}_{\mathrm{y}}\right]$ can also be set to represent the long-term evolution of equivalent effective stratospheric chlorine (EESC; e.g., Newman et al., 2007), an estimate of the total effective amount of halogens in the stratosphere. To compare the normalized model abundances with observations of vortex-averaged mixing ratios, the following scaling factors have been used for $460 \mathrm{~K}$ :

$$
\begin{aligned}
& F_{\mathrm{Cl}_{\mathrm{y}}}=2.7 \times 10^{-9}, \\
& F_{\mathrm{HNO}_{3}}=10.6 \times 10^{-9}, \\
& F_{\mathrm{dO}_{3} / \mathrm{d} t}=42.7 \times 10^{-9} \text { day }^{-1} .
\end{aligned}
$$

These factors were determined by dividing the averaged normalized model results by vortex-averaged observations from Match (for $\mathrm{d}[\mathrm{O} 3] / \mathrm{d} t$ ), MLS (for $[\mathrm{HCl}]$ and $\left[\mathrm{HNO}_{3}\right]$ ) and ACE-FTS (for $\left[\mathrm{ClONO}_{2}\right]$ ). Match is an approach to derive chemical ozone loss rates from coordinated ozonesonde observations (e.g., Rex et al., 1998). $\left[\mathrm{Cl}_{\mathrm{y}}\right]$ has been determined 
Table 3. List of parameters.

\begin{tabular}{cl}
\hline Parameter & Value \\
\hline$a$ & 0.135292 \\
$b$ & 0.437986 \\
$c$ & $1.578285 \times 10^{-3}$ \\
$d$ & $4.079051 \times 10^{-2}$ \\
$e$ & 0.022993 \\
$f$ & 0.209567 \\
$g$ & 0.508703 \\
$h$ & 0.455830 \\
$y$ & 0.250000 \\
$z$ & 0.579925 \\
\hline
\end{tabular}

from the sum of $[\mathrm{HCl}]$ and $\left[\mathrm{ClONO}_{2}\right]$ at the beginning of the winter.

A model with initial concentrations based on the scaling factors would give identical results to the normalized formulation described here. It would then calculate absolute values for the vortex-average mixing ratios and ozone loss rates rather than the normalized values shown here. The normalization moves the degrees of freedom, which usually are in the model initialization, to the scaling factors, an approach that is convenient for such a conceptual model.

\subsection{Training of the model}

The fit coefficients $a-h, y$ and $z$ of SWIFT (Table 3) are chosen such that the model best represents measurements of $\mathrm{HCl}, \mathrm{ClONO}_{2}$, gas-phase $\mathrm{HNO}_{3}$ and ozone loss rates as derived from observations. For this procedure, $\mathrm{HCl}$ and $\mathrm{HNO}_{3}$ measurements from MLS, $\mathrm{ClONO}_{2}$ from ACE-FTS and ozone loss rates from Match are used. For $\mathrm{HCl}, \mathrm{ClONO}_{2}$ and $\mathrm{HNO}_{3}$, vortex averages have been calculated from the individual data points, and the vortex averages on the retrieval surfaces have been interpolated to the potential temperature surface of $460 \mathrm{~K}$ that is used in the model. Ozone loss rates from Match represent vortex averages and have been retrieved on the model level.

FAP and FAS are calculated by assuming the vortex edge at the $31.2 \mathrm{PVU}$ potential vorticity contour. The area where the formation of nitric acid trihydrate (NAT) polar stratospheric clouds is possible is calculated from the equations given in Hanson and Mauersberger (1988) and divided by the vortex area to give FAP. For FAS, the area above a solar zenith angle of $95^{\circ}$ in the vortex is calculated and divided by the vortex area.

The model is trained on the seasonal evolution of these quantities during one Arctic winter (2004/2005) and one Antarctic winter (2006). In the Antarctic, Match ozone loss rates are only available for winter 2003, but MLS and ACEFTS data are not available for 2003. Since the meteorology during the 2003 Antarctic winter was reasonably similar to that in 2006, and FAP and FAS for these two Antarctic win- ters are not significantly different, we have used the ozone loss rates from the Match campaign in 2003 for the 2006 Antarctic winter.

The interannual variability of ozone loss is not used to train the model and can be used to validate the ability of the model to reproduce ozone loss under a wide range of meteorological conditions.

To train SWIFT, the model parameters are fitted to minimize a cost function, which is defined as the sum of the absolute values of the differences between all observations (divided by the scale factors) and the corresponding model values. For the ozone loss rates, the individual differences were weighted by the reciprocal of the uncertainty of the respective observation. For $\mathrm{HCl}$ and $\mathrm{ClONO}_{2}$, the individual uncertainties of the vortex-averaged observations are assumed to be equal for all dates.

Calculating the differences from the normalized data ensures that the same weights are used for all chemical species, independent of their absolute abundance. But since ozone loss rates are 2 orders of magnitude smaller than the normalized abundances of the chemical species (ozone loss rates are on the order of percent per day), their differences were multiplied by 50 to give them a weight in the cost function that is comparable to that of the chemical species. In addition, the ozone loss rates of the model have been averaged over 14 days to match the time resolution of the Match ozone loss rate observations.

The average differences are calculated individually for all species, and these averages are summed to give the cost function, weighted by the reciprocal of the average uncertainty of the measurements of that species. This results in identical weights for all species even if the number of available measurements is different.

The numerical algorithm described in Huck et al. (2013) has been used to solve the optimization problem. The set of parameters determined by the optimization procedure is listed in Table 3. To limit the degrees of freedom in the fitting procedure, the "PSC threshold" parameter $y$ has not been fitted but is estimated from Fig. 2.13 of WMO (2011).

\section{Results}

Figures 2 and 3 show the evolution of the model species throughout the Arctic winter 2004/2005 and the Antarctic winter 2006, respectively. Overall, the model reproduces the seasonal evolution of the key species and of the observed ozone loss rates throughout these winters well. Remaining differences between the SWIFT model and the observations can be explained well by the measurement error of the Match and satellite data, which causes inconsistencies between the different time series that the model is fitted to (see the error bars on the Match measurements, which represent $1 \sigma$ uncertainties). Figure 4 shows results for some additional Arctic winters, for which either satellite data or Match data 


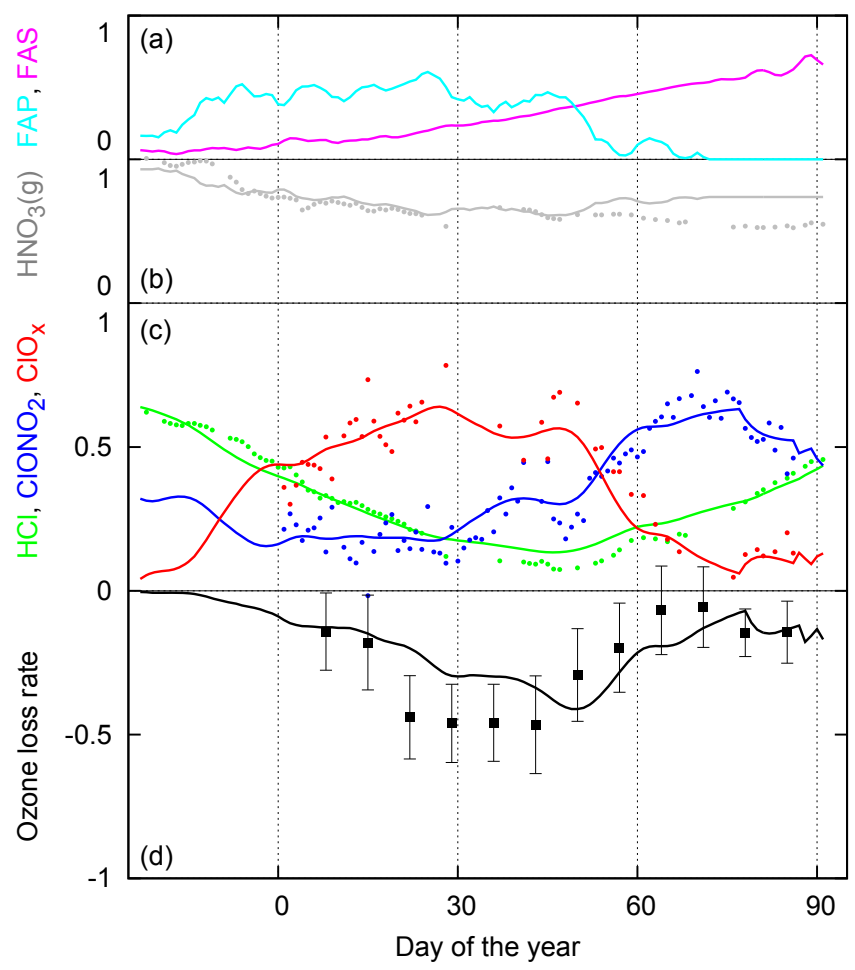

Figure 2. Overview of SWIFT results and observations for the Arctic winter 2004/2005. All data are shown in normalized units (more details see text). (a) FAP (cyan) and FAS (magenta). Lines in (b)(d) represent SWIFT results; dots represent vortex-averaged observations. (b) $\mathrm{HNO}_{3}$ (gas phase, gray, observations from Aura MLS). (c) $\mathrm{HCl}$ (green, observations from Aura MLS), $\mathrm{ClONO}_{2}$ (blue, observations from ACE-FTS) and $\mathrm{ClO}_{\mathrm{x}}$ (red, "observed" $\mathrm{ClO}_{\mathrm{x}}$ is derived by using a constant $\mathrm{Cl}_{\mathrm{y}}$ minus the $\mathrm{HCl}$ and $\mathrm{ClONO}_{2}$ observations). (c) Ozone loss rates (observations from Match). The loss rates of normalized ozone have been multiplied by 50 to facilitate plotting on the same scale. Error bars represent $1 \sigma$ statistical uncertainties; an additional $20 \%$ systematic uncertainty applies.

are available for comparison. These winters cover a range of different meteorological conditions, including one with very late ozone loss (1996/1997), a warm winter with little ozone loss (1997/1998) and one with complicated dynamics, which is a challenge for this simple chemical model (2007/2008).

To assess the interannual variation of the calculated ozone loss, the time-integrated normalized mixing ratio loss at $460 \mathrm{~K}$ (i.e., a value ranging from zero for no loss to one for complete loss of ozone) is used as a proxy for the column ozone loss, by multiplying it with a factor of $260 \mathrm{DU}$. This factor has been determined by fitting the normalized mixing ratios to column loss observations. Figure 5 shows the interannual variation of the proxy total ozone loss compared with total ozone loss observations (updated from Rex et al., 2006). The agreement of the absolute values is caused by fitting the scaling factor to observations, but the correlation between the time series is very good.

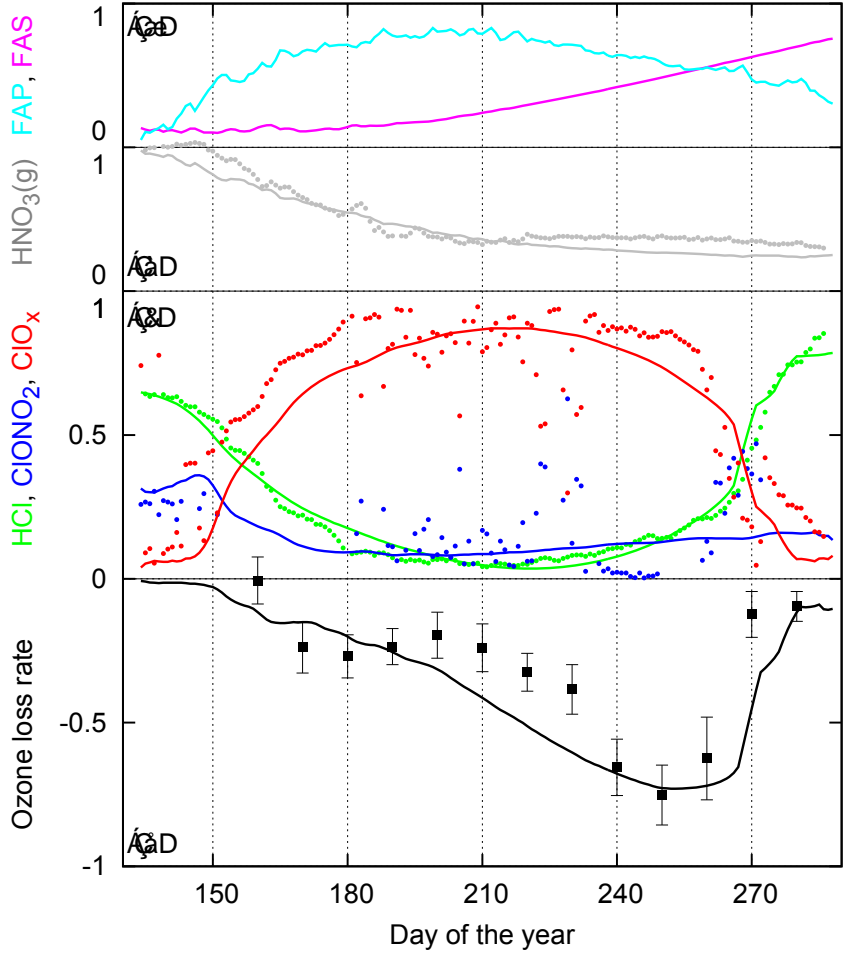

Figure 3. As Fig. 2, but for the Antarctic winter 2006.

\section{Discussion and conclusions}

In this work, a semi-empirical approach to modeling stratospheric ozone loss in both the Arctic and Antarctic has been developed with the goal of simulating as faithfully as possible the chemical mechanisms that drive polar ozone loss with a simple and fast model of vortex-average quantities.

SWIFT provides a good representation of polar ozone loss for a wide range of vortex conditions in the current climate, including the range between warm and disturbed Arctic winters to the coldest Antarctic winters. The mechanisms in SWIFT are chemically and physically representative of realworld processes. SWIFT is extremely fast and processes several hundreds of years per second.

SWIFT includes parameters for the individual chemical mechanisms that replace the reaction kinetic parameters of full chemical models. In principle, most of these parameters can be linked to the underlying reaction kinetic parameters that are usually determined from laboratory measurements. However, in SWIFT these parameters are trained on observations of the atmosphere, rather than on observations in the laboratory. It is important to note that these empirical parameters are intrinsic physical properties of the involved molecules and mechanisms, and do not change with changing climate conditions. Hence SWIFT will still give a good representation of the chemical conditions inside the polar vortices in a changing climate, unless the meteorological conditions become so drastically different from the range 

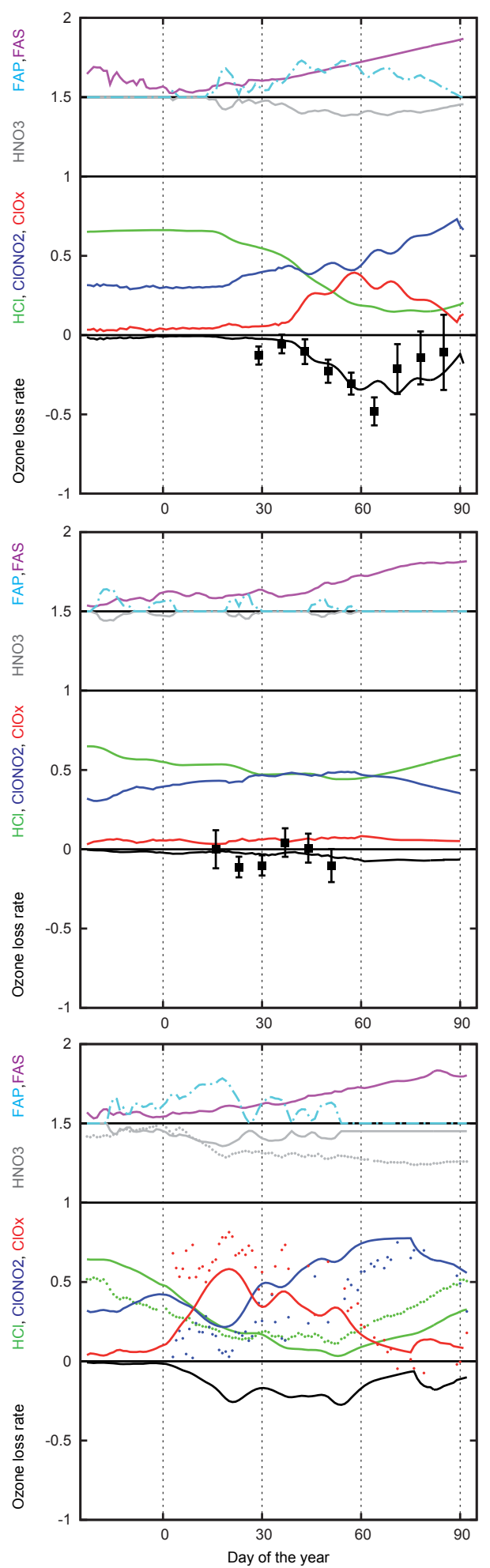

Figure 4. Same as Fig. 2 for the Arctic winters 1996/1997 (top), 1997/1998 (middle) and 2007/2008 (bottom). Match data are only available for 1996/1997 and 1997/1998 and satellite data only for 2007/2008.

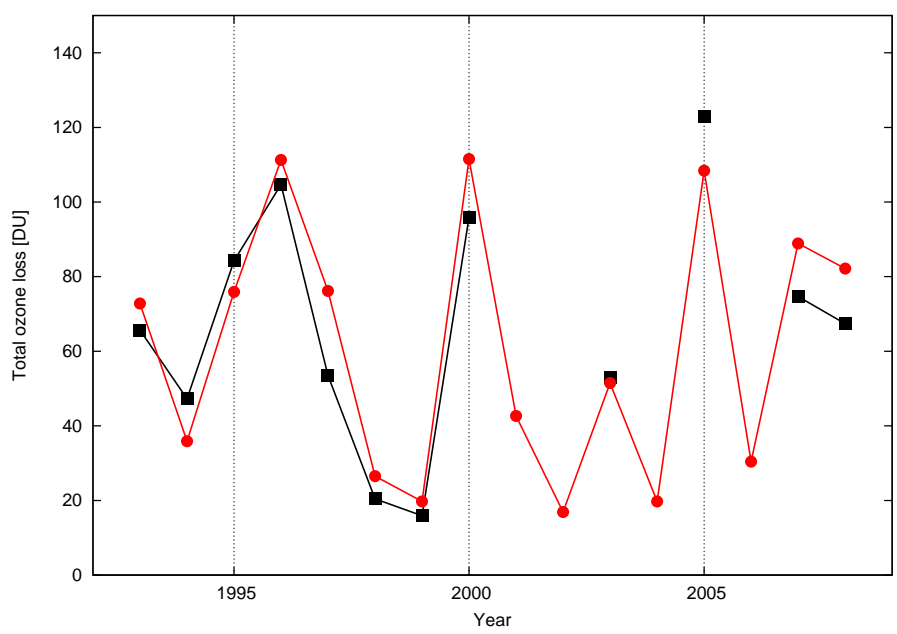

Figure 5. Year-to-year variability in total chemical ozone loss in the Arctic estimated from SWIFT (red) compared with observations (black; Rex et al., 2006).

of present-day conditions that currently unimportant mechanisms become relevant. However, climate models do not suggest that such dramatic climate change will occur during the next century or so.

In contrast, the ability of existing fast ozone chemistry models like Linoz to cope with changing climate conditions is limited. While there is some ability to model the effect of temperature changes at midlatitudes by the Taylor expansion around temperature, changes in the heterogenous polar chemistry, changes in the abundances of the chlorine source gases and non-linear changes cannot be accounted for. In addition, since our model is based on differential equations, it does not only take into account the current state of the atmosphere, but also the meteorological history.

SWIFT includes all major feedbacks between climate change and polar ozone loss. However, in its current version SWIFT does not include all potential feedbacks; e.g., changes in stratospheric age of air or changes of $\mathrm{NO}_{\mathrm{y}}$ or total sulfate are currently not accounted for, but many of these can be included in future versions of the model.

The semi-empirical model described here can also be used for the ozone loss in individual air masses as a semiempirical box model. The parameters FAP and FAS would then be defined to give the fractional time the individual air mass spends in PSC conditions or in sunlight, respectively, and a different set of fitting parameters has to be determined, e.g., by using a box model with full chemistry for the training of the semi-empirical model. 
Acknowledgements. This work was supported by the BMBF under the FAST-O3 project in the MiKliP framework programme (FKZ 01LP1137A) and by the European Community within the StratoClim project (grant no. 603557). Work at Bodeker Scientific was supported in part by a New Zealand Antarctic Research Institute-funded project. The ACE mission is supported primarily by the Canadian Space Agency. We thank ECMWF for providing reanalysis data. Work at the Jet Propulsion Laboratory, California Institute of Technology, was done under contract with the National Aeronautics and Space Administration.

Edited by: Q. Errera

\section{References}

Austin, J.: A three-dimensional coupled chemistry-climate model simulation of past stratospheric trends, J. Atmos. Sci., 59, 218 232, 2002.

Bernath, P. F., McElroy, C. T., Abrams, M. C., Boone, C. D., Butler, M., Camy-Peyret, C., Carleer, M., Clerbaux, C., Coheur, P.-F., Colin, R., DeCola, P., DeMazière, M., Drummond, J. R., Dufour, D., Evans, W. F. J., Fast, H., Fussen, D., Gilbert, K., Jennings, D. E., Llewellyn, E. J., Lowe, R. P., Mahieu, E., McConnell, J. C., McHugh, M., McLeod, S. D., Michaud, R., Midwinter, C., Nassar, R., Nichitiu, F., Nowlan, C., Rinsland, C. P., Rochon, Y. J., Rowlands, N., Semeniuk, K., Simon, P., Skelton, R., Sloan, J. J., Soucy, M.-A., Strong, K., Tremblay, P., Turnbull, D., Walker, K. A., Walkty, I., Wardle, D. A., Wehrle, V., Zander, R., and Zou, J.: Atmospheric Chemistry Experiment (ACE): Mission overview, Geophys. Res. Lett., 32, L15S01, doi:10.1029/2005GL022386, 2005.

Bourqui, M. S., Taylor, C. P., and Shine, K. P.: A new fast stratospheric ozone chemistry scheme in an intermediate generalcirculation model. II: Application to effects of future increases in greenhouse gases, Q. J. Roy. Meteorol. Soc., 131, 2243-2261, 2005.

Braesicke, P., Hurwitz, M. M., and Pyle, J. A.: The stratospheric response to changes in ozone and carbon dioxide as modelled with a GCM including parameterised ozone chemistry, Meteorol. Z., 15, 343-354, 2006.

Cariolle, D. and Déqué, M.: Southern hemisphere medium-scale waves and total ozone disturbances in a spectral general circulation model, J. Geophys. Res., 91, 10825-10846, 1986.

Cariolle, D. and Teyssèdre, H.: A revised linear ozone photochemistry parameterization for use in transport and general circulation models: multi-annual simulations, Atmos. Chem. Phys., 7, 21832196, doi:10.5194/acp-7-2183-2007, 2007.

Cariolle, D., Lasserre-Bigory, A., and Royer, J. F.: A general circulation model simulation of the springtime Antarctic ozone and its impact on mid-latitudes, J. Geophys. Res., 95, 1883-1898, 1990.

Dee, D. P., Uppala, S. M., Simmons, A. J., Berrisford, P., Poli, P., Kobayashi, S., Andrae, U., Balmaseda, M. A., Balsamo, G., Bauer, P., Bechtold, P., Beljaars, A. C. M., van de Berg, L., Bidlot, J., Bormann, N., Delsol, C., Dragani, R., Fuentes, M., Geer, A. J., Haimberger, L., Healy, S. B., Hersbach, H., Hólm, E. V., Isaksen, L., Kållberg, P., Köhler, M., Matricardi, M., McNally, A. P., Monge-Sanz, B. M., Morcrette, J.-J., Park, B.-K., Peubey, C., de Rosnay, P., Tavolato, C., Thépaut, J.-N., and Vitart, F.: The ERA-Interim reanalysis: configuration and performance of the data assimilation system, Q. J. Roy. Meteorol. Soc., 137, 553597, 2011.

Eyring, V., Butchart, N., Waugh, D. W., Akiyoshi, H., Austin, J., Bekki, S., Bodeker, G. E., Boville, B. A., Brühl, C., Chipperfield, M. P., Cordero, E., Dameris, M., Deushi, M., Fioletov, V. E., Frith, S. M., Garcia, R. R., Gettelman, A., Giorgetta, M. A., Grewe, V., Jourdain, L., Kinnison, D. E., Mancini, E., Manzini, E., Marchand, M., Marsh, D. R., Nagashima, T., Newman, P. A., Nielsen, J. E., Pawson, S., Pitari, G., Plummer, D. A., Rozanov, E., Schraner, M., Shepherd, T., Shibata, K., Stolarski, R. S., Struthers, H., Tian, W., and Yoshiki, M.: Assessment of temperature, trace species, and ozone in chemistry-climate model simulations of the recent past, J. Geophys. Res., 111, D22308, doi:10.1029/2006JD007327, 2006.

Eyring, V., Waugh, D. W., Bodeker, G. E., Cordero, E., Akiyoshi, H., Austin, J., Beagley, S. R., Boville, B. A., Braesicke, P., Brühl, C., Butchart, N., Chipperfield, M. P., Dameris, M., Deckert, R., Deushi, M., Frith, S. M., Garcia, R. R., Gettelman, A., Giorgetta, M. A., Kinnison, D. E., Mancini, E., Manzini, E., Marsh, D. R., Matthes, S., Nagashima, T., Newman, P. A., Nielsen, J. E., Pawson, S., Pitari, G., Plummer, D. A., Rozanov, E., Schraner, M., Scinocca, J. F., Semeniuk, K., Shepherd, T. G., Shibata, K., Steil, B., Stolarski, R. S., Tian, W., and Yoshiki, M.: Multimodel projections of stratospheric ozone recovery in the 21st century, J. Geophys. Res., 112, D16303, doi:10.1029/2006JD008332, 2007.

Forster, P. M. and Shine, K. P.: Radiative forcing and temperature trends from stratospheric ozone changes, J. Geophys. Res., 102, 10841-10855, 1997.

Forster, P. M., Bodeker, G. E., Schofield, R., Solomon, S., and Thompson, D. W. J.: Effects of ozone cooling in the tropical lower stratosphere and upper troposphere, Geophys. Res. Lett., 34, L23813, doi:10.1029/2007GL031994, 2007.

Frieler, K., Rex, M., Salawitch, R. J., Canty, T., Streibel, M., Stimpfle, R., Pfeilsticker, K., Dorf, M., Weisenstein, D. K., and Godin-Beekman, S.: Towards a better quantitative understanding of polar stratospheric ozone loss, Geophys. Res. Lett., 33, L10812, doi:10.1029/2005GL025466, 2006.

Gauss, M., Myhre, G., Isaksen, I. S. A., Grewe, V., Pitari, G., Wild, O., Collins, W. J., Dentener, F. J., Ellingsen, K., Gohar, L. K., Hauglustaine, D. A., Iachetti, D., Lamarque, F., Mancini, E., Mickley, L. J., Prather, M. J., Pyle, J. A., Sanderson, M. G., Shine, K. P., Stevenson, D. S., Sudo, K., Szopa, S., and Zeng, G.: Radiative forcing since preindustrial times due to ozone change in the troposphere and the lower stratosphere, Atmos. Chem. Phys., 6, 575-599, doi:10.5194/acp-6-575-2006, 2006.

Hadjinicolaou, P., Pyle, J. A., and Harris, N. R. P.: The recent turnaround in stratospheric ozone over northern middle latitudes: A dynamical modeling perspective, Geophys. Res. Lett., 32, L12821, doi:10.1029/2005GL022476, 2005.

Hanson, D. and Mauersberger, K.: Laboratory studies of the nitric acid trihydrate: Implications for the south polar stratosphere, Geophys. Res. Lett., 15, 855-858, 1988.

Harris, N. R. P., Lehmann, R., Rex, M., and von der Gathen, P.: A closer look at Arctic ozone loss and polar stratospheric clouds, Atmos. Chem. Phys., 10, 8499-8510, doi:10.5194/acp-10-84992010, 2010.

Hsu, J. and Prather, M. J.: Stratospheric variability and tropospheric ozone, J. Geophys. Res., 114, D06102, doi:10.1029/2008JD010942, 2009. 
Huck, P. E., Bodeker, G. E., Kremser, S., McDonald, A. J., Rex, M., and Struthers, H.: Semi-empirical models for chlorine activation and ozone depletion in the Antarctic stratosphere: proof of concept, Atmos. Chem. Phys., 13, 3237-3243, doi:10.5194/acp13-3237-2013, 2013.

IPCC: Climate Change 2013: The Physical Science Basis. Contribution of Working Group I to the Fifth Assessment Report of the Intergovernmental Panel on Climate Change, edited by: Stocker, T. F., Qin, D., Plattner, G.-K., Tignor, M. M. B., Allen, S. K., Boschung, J., Nauels, A., Xia, Y., Bex, V., and Midgley, P. M., Cambridge University Press, Cambridge, UK and New York, USA, 2013.

Livesey, N. J., Read, W. G., Froidevaux, L., Lambert, A., Manney, G. L., Pumphrey, H. C., Santee, M. L., Schwartz, M. J., Wang, S., Cofeld, R. E., Cuddy, D. T., , Fuller, R. A., Jarnot, R. F., Jiang, J. H., Knosp, B. W., Stek, P. C., Wagner, P. A., and Wu, D. L.: Version 3.3 Level 2 data quality and description document, JPL D-33509, http://mls.jpl.nasa.gov, 2011.

McLinden, C. A., Olsen, S. C., Hannegan, B. J., Wild, O., and Prather, M. J.: Stratospheric ozone in 3-D models: a simple chemistry and the cross-tropopause flux, J. Geophys. Res., 105, 14653-14665, 2000.

Newman, P. A., Daniel, J. S., Waugh, D. W., and Nash, E. R.: A new formulation of equivalent effective stratospheric chlorine (EESC), Atmos. Chem. Phys., 7, 4537-4552, doi:10.5194/acp7-4537-2007, 2007.

Pitts, M. C., Thomason, L. W., Poole, L. R., and Winker, D. M.: Characterization of Polar Stratospheric Clouds with spaceborne lidar: CALIPSO and the 2006 Antarctic season, Atmos. Chem. Phys., 7, 5207-5228, doi:10.5194/acp-7-5207-2007, 2007.

Rex, M., von der Gathen, P., Harris, N. R. P., Lucic, D., Knudsen, B. M., Braathen, G. O., Reid, S. J., De Backer, H., Claude, H., Fabian, R., Fast, H., Gil, M., Kyrö, E., Mikkelsen, I. S., Rummukainen, M., Smit, H. G., Stähelin, J., Varotsos, C., and Zaitcev, I.: In-situ measurements of stratospheric ozone depletion rates in the Arctic winter 1991/1992: A Lagrangian approach, J. Geophys. Res., 103, 5843-5853, 1998.

Rex, M., Salawitch, R. J., Deckelmann, H., von der Gathen, P., Harris, N. R. P., Chipperfield, M. P., Naujokat, B., Reimer, E., Allaart, M., Andersen, S. B., Bevilacqua, R., Braathen, G. O., Claude, H., Davies, J., De Backer, H., Dier, H., Dorokhov, V., Fast, H., Gerding, M., Godin-Beekmann, S., Hoppel, K., Johnson, B., Kyrö, E., Litynska, Z., Moore, D., Nakane, H., Parrondo, M. C., Risley Jr., A. D., Skrivankova, P., Stübi, R., Viatte, P., Yushkov, V., and Zerefos, C.: Arctic winter 2005: Implications for stratospheric ozone loss and climate change, Geophys. Res. Lett., 33, L23808, doi:10.1029/2006GL026731, 2006.
Santee, M. L., MacKenzie, I. A., Manney, G. L., Chipperfield, M. P., Bernath, P. F., Walker, K. A., Boone, C. D., Froidevaux, L., Livesey, N. J., and Waters, J. W.: A study of stratospheric chlorine partitioning based on new satellite measurements and modeling, J. Geophys. Res., 113, D12307, doi:10.1029/2007JD009057, 2008.

Solomon, S.: Stratospheric ozone depletion: A review of concepts and history, Rev. Geophys., 37, 275-316, 1999.

von Hobe, M., Bekki, S., Borrmann, S., Cairo, F., D’Amato, F., Di Donfrancesco, G., Dörnbrack, A., Ebersoldt, A., Ebert, M., Emde, C., Engel, I., Ern, M., Frey, W., Genco, S., Griessbach, S., Grooß, J.-U., Gulde, T., Günther, G., Hösen, E., Hoffmann, L., Homonnai, V., Hoyle, C. R., Isaksen, I. S. A., Jackson, D. R., Jánosi, I. M., Jones, R. L., Kandler, K., Kalicinsky, C., Keil, A., Khaykin, S. M., Khosrawi, F., Kivi, R., Kuttippurath, J., Laube, J. C., Lefèvre, F., Lehmann, R., Ludmann, S., Luo, B. P., Marchand, M., Meyer, J., Mitev, V., Molleker, S., Müller, R., Oelhaf, H., Olschewski, F., Orsolini, Y., Peter, T., Pfeilsticker, K., Piesch, C., Pitts, M. C., Poole, L. R., Pope, F. D., Ravegnani, F., Rex, M., Riese, M., Röckmann, T., Rognerud, B., Roiger, A., Rolf, C., Santee, M. L., Scheibe, M., Schiller, C., Schlager, H., Siciliani de Cumis, M., Sitnikov, N., Søvde, O. A., Spang, R., Spelten, N., Stordal, F., Sumińska-Ebersoldt, O., Ulanovski, A., Ungermann, J., Viciani, S., Volk, C. M., vom Scheidt, M., von der Gathen, P., Walker, K., Wegner, T., Weigel, R., Weinbruch, S., Wetzel, G., Wienhold, F. G., Wohltmann, I., Woiwode, W., Young, I. A. K., Yushkov, V., Zobrist, B., and Stroh, F.: Reconciliation of essential process parameters for an enhanced predictability of Arctic stratospheric ozone loss and its climate interactions (RECONCILE): activities and results, Atmos. Chem. Phys., 13, 92339268, doi:10.5194/acp-13-9233-2013, 2013.

WMO: World Meteorological Organization (WMO)/United Nations Environment Programme (UNEP), Scientific assessment of ozone depletion: 2010, Global Ozone Research and Monitoring Project - Report No. 52, 2011.

Wohltmann, I., Wegner, T., Müller, R., Lehmann, R., Rex, M., Manney, G. L., Santee, M. L., Bernath, P., Sumińska-Ebersoldt, O., Stroh, F., von Hobe, M., Volk, C. M., Hösen, E., Ravegnani, F., Ulanovsky, A., and Yushkov, V.: Uncertainties in modelling heterogeneous chemistry and Arctic ozone depletion in the winter 2009/2010, Atmos. Chem. Phys., 13, 3909-3929, doi:10.5194/acp-13-3909-2013, 2013. 